\title{
NOTES
}

\section{Monomer Formation from Polyisobutylene in the Presence of $\mathrm{SiO}_{2}-\mathrm{Al}_{2} \mathrm{O}_{3}$ Catalyst}

\author{
Hidesaburo NANBU, Yumiko IshiHARA, Tomoyuki TAKeSUE, \\ and Tadashi IKEMURA \\ Department of Industrial Chemistry, College of Science and Technology, \\ Nihon University, 1-8 Kandasurugadai, Chiyoda-ku, \\ Tokyo 101, Japan
}

(Received April 25, 1986)

KEY WORDS Silica-Alumina Catalyst / Catalytic Degradation / Polyisobutylene /

We have made a systematic study on polymer degradation in the presence of solid catalysts, ${ }^{1-5}$ in which the degradation of high-density polyethylene with $\mathrm{SiO}_{2}-\mathrm{Al}_{2} \mathrm{O}_{3}$ catalyst led to the formation of various types of branches in the main chain ${ }^{1}$ and that of polystyrene with the same catalyst also gave a partly indan-skeleton structure in the polymer. ${ }^{2}$ In this study, the degradation of polyisobutylene at $120 \sim 240^{\circ} \mathrm{C}$ in the presence of $\mathrm{SiO}_{2}-\mathrm{Al}_{2} \mathrm{O}_{3}$ catalyst is studied and in particular, the effect of concentration of terminal olefins on isobutylene monomer formation is discussed.

\section{EXPERIMENTAL}

Two types of polyisobutylene were used in the present study. Sample A (abbreviated as PIB-A) containing no additives was purchased from Nippon Oil Co., Ltd. The number average molecular weight $\left(\bar{M}_{n}\right)$ of PIB-A was $2.2 \times 10^{4}$ and it was used without further purification. Sample B (abbreviated as PIBB) was prepared by thermal treating a commercial polyisobutylene $\left(\bar{M}_{n}=1.4 \times 10^{5}\right.$, Exxon Chemical Japan Ltd.) at $350^{\circ} \mathrm{C}$ for $1 \mathrm{~h}$ under reduced pressure of $4 \mathrm{mmHg}$. The
$\bar{M}_{n}$ of PIB-B determined by viscosity method $\left([\eta]=1.86 \times 10^{-2} \cdot \bar{M}_{n}^{0.76}\right)^{6}$ was $3.8 \times 10^{3}$. $\mathrm{SiO}_{2}-\mathrm{Al}_{2} \mathrm{O}_{3}$ catalyst $\left(\mathrm{Al}_{2} \mathrm{O}_{3}=13 \mathrm{wt} \%\right)$, supplied by Catalysts and Chemicals I.N.D. Co., was crushed into less than 100 mesh, followed by calcination in air at $540^{\circ} \mathrm{C}$ for $3 \mathrm{~h}$ prior to use. A given polyisobutylene sample $(2 \mathrm{~g})$ and the calcined catalyst $(2 \mathrm{~g})$ were mixed in a $\mathrm{N}_{2}$-purged glass tube $(\phi 25 \mathrm{~mm} \times 240 \mathrm{~mm})$ and then the tube was soaked in a metal bath controlled at a given temperature. After the reaction, the product was analyzed by GLC (Shimadzu GC-6A), GPC (Toyo Soda HLC 802 UR) and PFT $-{ }^{1} \mathrm{H}$ NMR (Jeol JNM-FX 100).

\section{RESULTS AND DISCUSSION}

Figure 1 shows ${ }^{1} \mathrm{H}$ NMR spectra of starting PIB-A and PIB-B. A signal at $1.11 \mathrm{ppm}$ belongs to methyl protons in the side-chain groups and $1.41 \mathrm{ppm}$ to methylene protons in the main chain of both polymers. Three peaks at $3-6 \mathrm{ppm}$ in the spectrum of PIB-B were assigned to the terminal-vinylidenetype olefin ( 4.64 and $4.84 \mathrm{ppm}$ ) and the terminal-trisubstituted-type olefin $(5.14 \mathrm{ppm}){ }^{7}$ The total concentration of terminal olefins 
in PIB-B determined by ${ }^{1} \mathrm{H}$ NMR was $4.3 \times$ $10^{-4} \mathrm{~mol} \mathrm{~g}^{-1}$ ([terminal-vinylidene-type olefin] $=1.3 \times 10^{-4} \mathrm{~mol} \mathrm{~g}^{-1}$ ) and [terminal-trisubstituted-type olefin] $=3.0 \times 10^{-4} \mathrm{~mol} \mathrm{~g}^{-1}$ ). On the other hand, the total concentration of terminal olefins in PIB-A was $4.3 \times$ $10^{-6} \mathrm{molg}^{-1}$, which was ca. $1 / 100$ that for PIB-B, and thus the value for PIB-A was almost negligible. These quantifications indicate that about 2 terminal olefinic residues exist in every molecule, and thus possible structures of PIB-B are as follows:

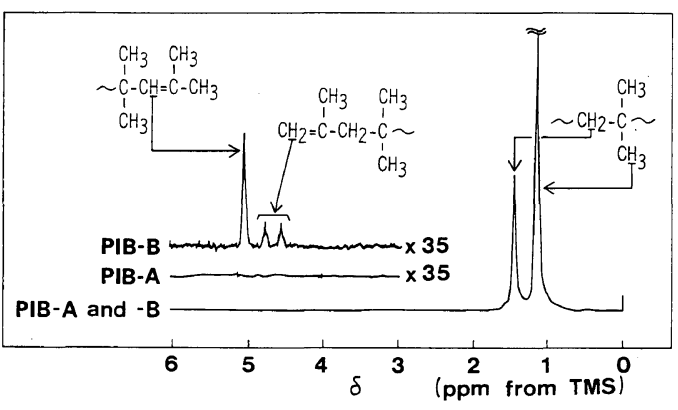

Figure 1. ${ }^{1} \mathrm{H}$ NMR spectra of PIB-A and PIB-B: solvent, $\mathrm{CDCl}_{3}$.

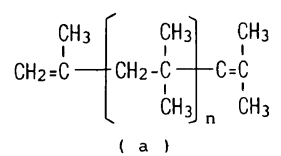

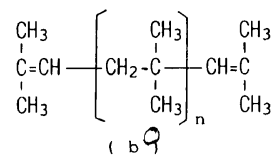

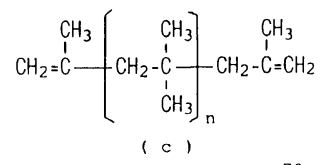

$+70$
Among these structures, most of PIB-B molecules belong to (a) and (b) on the basis of the concentration and the type of olefins determined by ${ }^{1} \mathrm{H}$ NMR.

Figure 2 shows the yield of isobutylene monomer and $\bar{M}_{n}$ of the degraded PIB-A with and without $\mathrm{SiO}_{2}-\mathrm{Al}_{2} \mathrm{O}_{3}$ catalyst under the reaction conditions at $160-330^{\circ} \mathrm{C}$ for $1 \mathrm{~h}$. The monomer yield without the catalyst was $1.0 \%$ at $300^{\circ} \mathrm{C}$ and increased to $20.0 \%$ at $330^{\circ} \mathrm{C}$. The $\bar{M}_{n}$ of PIB-A decreased rapidly above $250^{\circ} \mathrm{C}$. Similar decreases in molecular weight are confirmed by various papers $^{8,9}$ and are interpreted by a random intermolecular chain transfer macroradicals followed by $\beta$-scission. ${ }^{8}$ The isobutylene monomer is formed by $\beta$-scission of these terminal macroradicals.

The monomer yield with the catalyst was $1.9 \%$ even at $160^{\circ} \mathrm{C}$ and increased to $22.0 \%$ at $250^{\circ} \mathrm{C}$. The monomer formation with the catalyst takes place to an appreciable extent at lower temperatures and no molecular weight decrease was observed. These results clearly indicate that $\mathrm{SiO}_{2}-\mathrm{Al}_{2} \mathrm{O}_{3}$ catalyst promotes the formation of isobutylene monomer without molecular weight decrease.

PIB-B, which has terminal olefins, with

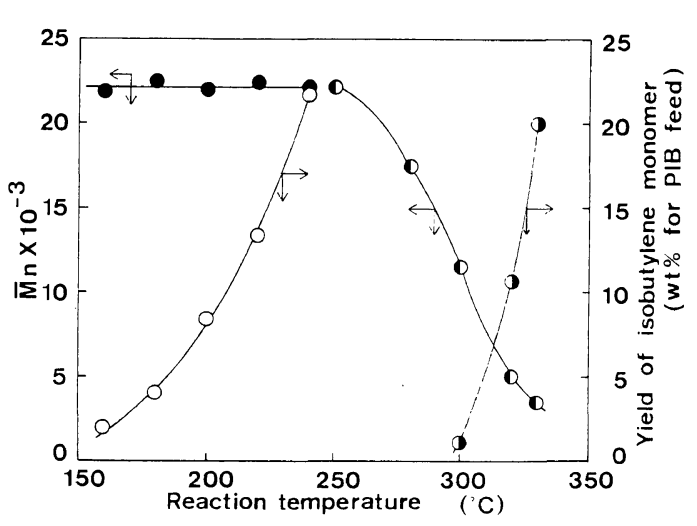

Figure 2. Difference between catalytic and thermal degradation of polyisobutylene (PIB-A) based on monomer yield and number average molecular weight: $\mathrm{O}$ and $O$, with $\mathrm{SiO}_{2}-\mathrm{Al}_{2} \mathrm{O}_{3}$ catalyst; $\mathrm{O}$ and $\mathrm{O}$, without $\mathrm{SiO}_{2}-\mathrm{Al}_{2} \mathrm{O}_{3}$ catalyst; reaction time, $1 \mathrm{~h}$.

$\mathrm{SiO}_{2}-\mathrm{Al}_{2} \mathrm{O}_{3}$ catalyst gave the monomer at considerably low temperatures, even at $120^{\circ} \mathrm{C}$ which was lower by $c a .40^{\circ} \mathrm{C}$ than that for the PIB-A performance (Figure 3). The monomer yield from PIB-B increased to $19.8 \%$ at $200^{\circ} \mathrm{C}$, which was ca. 2 times as large as that from PIB-A. This result suggests that the terminal olefins in polyisobutylene are apparently activated by $\mathrm{SiO}_{2}-\mathrm{Al}_{2} \mathrm{O}_{3}$ catalyst to form the monomer.

Table I shows the changes in monomer yield 


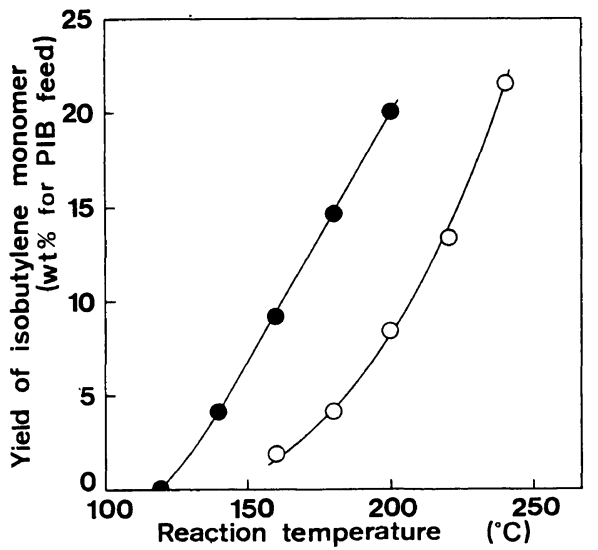

Figure 3. Effects of polyisobutylene samples on the yield of isobutylene monomer: $\bigcirc$, PIB-A; O, PIB-B; reaction time, $1 \mathrm{~h}$.

Table I. Effects of the concentration of terminal olefins in PIB-B on monomer formation ${ }^{\mathrm{a}}$

\begin{tabular}{lcc}
\hline \multicolumn{1}{c}{ Sample } & $\begin{array}{c}\text { Terminal } \\
\text { olefins } \\
\text { Concentration } \\
\left(\times 10^{-4} \mathrm{~mol} \mathrm{~g}^{-1}\right)\end{array}$ & $\begin{array}{c}\text { Yield of } \\
\text { monomer } \\
(\mathrm{wt} \% \text { for } \\
\text { PIB feed })\end{array}$ \\
\hline PIB-B Original & 4.3 & 19.8 \\
$30 \%$ Hydrogenated & 3.0 & 15.9 \\
$58 \%$ Hydrogenated & 1.8 & 7.0 \\
$88 \%$ Hydrogenated & 0.5 & 5.2 \\
\hline
\end{tabular}

a Reaction temp, $200^{\circ} \mathrm{C}$; time, $1 \mathrm{~h}$.

as a function of the concentration of terminal olefins in PIB-B in order to demonstrate the promotional effect of terminal olefins on monomer formation. The monomer formation decreased from 19.8 to $5.2 \%$ as the concentration of terminal olefins in PIB-B decreased from $4.3 \times 10^{-4}$ to $0.5 \times 10^{-4} \mathrm{~mol} \mathrm{~g}^{-1}$. The data in Table I show that terminal olefins promote monomer formation in the presence of $\mathrm{SiO}_{2}-\mathrm{Al}_{2} \mathrm{O}_{3}$ catalyst.

The monomer yield from PIB-B decreased from 19.8 to $0 \%$ when $\mathrm{SiO}_{2}-\mathrm{Al}_{2} \mathrm{O}_{3}$ catalyst was poisoned by pyridine. This shows that acid sites of the $\mathrm{SiO}_{2}-\mathrm{Al}_{2} \mathrm{O}_{3}$ catalyst play an important role in monomer formation. As previously reported, $\mathrm{SiO}_{2}-\mathrm{Al}_{2} \mathrm{O}_{3}$ catalyst promoted the isomerization. of 2,4-diphenyl-1- butene $^{10}$ and the dephenylation of polystyrene $^{3,11}$ by Brönsted-acid sites of the catalyst. Thus, the promotional effects for the monomer formation may occur through the reaction sequence in eq 1 . On the other hand, on PIB-

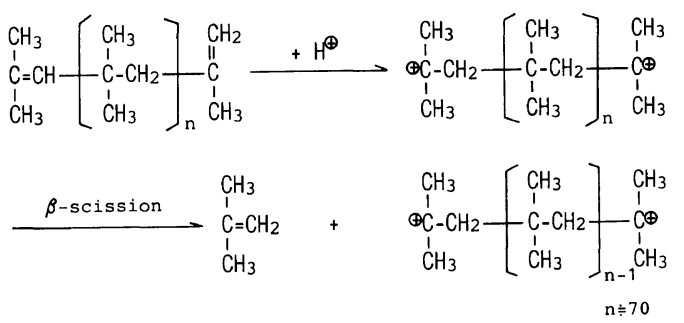

A with the catalyst, the monomer was also formed at temperatures above $150^{\circ} \mathrm{C}$ (Figure 2 ), even though the concentration of terminal olefins was negligibly small. This suggests that not only Brönsted-acid sites but also Lewisacid sites of the catalyst participate monomer formation at temperatures above $150^{\circ} \mathrm{C}$. The $\mathrm{SiO}_{2}-\mathrm{Al}_{2} \mathrm{O}_{3}$ catalyst has both Brönsted-acid and Lewis-acid sites. ${ }^{12}$

The GPC curves of catalytically degraded PIB-B at different temperatures consist basically of two peaks at the elution counts of 94 and 112, as shown in Figure 4. The elution count of 94 corresponds to unreacted PIB-B, while the elution count of 112 corresponds to 2-10 monomer-unit oligomers. The ${ }^{1} \mathrm{H}$ NMR spectrum of the oligomer is shown in Figure 5. This spectrum consists mostly of signals from original polymer (PIB-B). A few new signals are due to decrease in molecular weight and/or structural change. The peak area for the unreacted PIB-B in Figure 4 decreased with increasing reaction temperature, whereas that for 2-10 monomer-unit oligomers enhanced. The formation ratio of monomer to oligomer was approximately 1 to 3 under the conditions employed, and a similar phenomenon was observed for PIBA. The 2-10 monomer-unit oligomers therefore appear to be directly formed from original polyisobutylene.

In order to clarify the hypothesis stated 


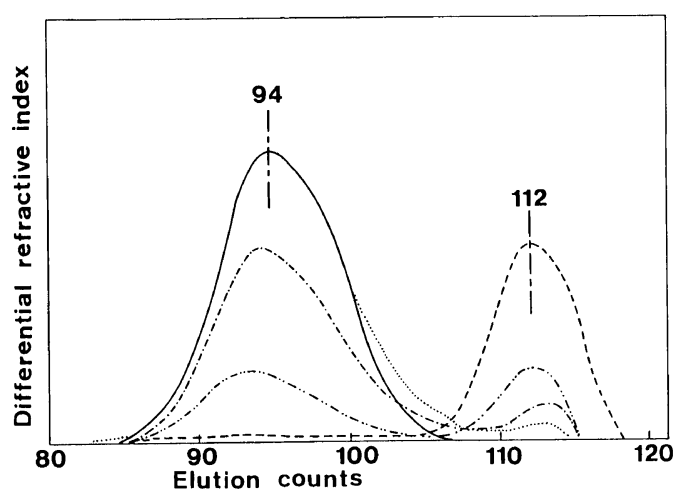

Figure 4. GPC curves of the degraded PIB-B in the presence of $\mathrm{SiO}_{2}-\mathrm{Al}_{2} \mathrm{O}_{3}$ catalyst: - , starting PIB-B; $\cdots \cdot$, at $120^{\circ} \mathrm{C} ;-\cdot-$, at $140^{\circ} \mathrm{C} ;-\cdot-$, at $160^{\circ} \mathrm{C} ;----$, at $200^{\circ} \mathrm{C}$; reaction time, $1 \mathrm{~h}$.

above, the degradation of these oligomers with $\mathrm{SiO}_{2}-\mathrm{Al}_{2} \mathrm{O}_{3}$ catalyst was performed at $200^{\circ} \mathrm{C}$ for $1 \mathrm{~h}$. No isobutylene monomer was formed from these oligomers. Thus, both monomer and 2-10 monomer-unit oligomers

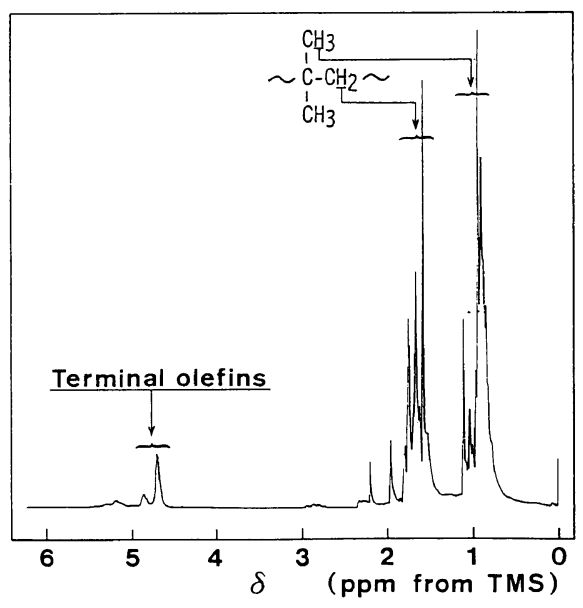

Figure 5. ${ }^{1} \mathrm{H}$ NMR spectrum of the 2-10 monomerunit oligomers from PIB-B with $\mathrm{SiO}_{2}-\mathrm{Al}_{2} \mathrm{O}_{3}$ catalyst: solvent, $\mathrm{CDCl}_{3}$.

are formed competitively from original polyisobutylene, as shown in eq 2 .

\section{Isobutylene monomer}<smiles>CC(C)(C)C</smiles>

In summary, isobutylene monomer formed appreciably even at $160^{\circ} \mathrm{C}$ in the presence of $\mathrm{SiO}_{2}-\mathrm{Al}_{2} \mathrm{O}_{3}$ catalyst, which was lower by $c a$. $140^{\circ} \mathrm{C}$ than that in the absence of catalyst. The monomer yield increased with increasing concentration of terminal olefins in polyisobutylene, since these olefinic molecules are effectively activated by the acid sites of $\mathrm{SiO}_{2}-\mathrm{Al}_{2} \mathrm{O}_{3}$ catalyst.

\section{REFERENCES}

1. H. Nanbu, H. Honma, Y. Isihara, T. Takesue, and T. Ikemura, Preprints, The 51th National Meeting of the Chemical Society of Japan, (II), 1985, p 792.
2. S. Ide, T. Ogawa, T. Kuroki, and T. Ikemura, $J$. Appl. Polym. Sci., 29, 2561 (1984).

3. S. Ide, H. Nanbu, T. Kuroki, and T. Ikemura, Nippon Kagaku Kaishi, 1657 (1983).

4. S. Ide, H. Nanbu, T. Ogawa, T. Kuroki, and T. Ikemura, Kobunshi Ronbunshu, 41, 69 (1984).

5. S. Ide, T. Ogawa, T. Kuroki, and T. Ikemura, Nenryo Kyokaishi, 63, 185 (1984).

6. Y. Sakaguchi and I. Sakurada, Kobunshi Kagaku, 5, 242 (1948).

7. T. Kuroki, T. Sawaguchi, K. Suzuki, S. Ide, and T Ikemura, Polymer, 24, 428 (1983).

8. S. L. Malhotra, L. Y. Minh, and L. P. Blanchard, J. Macromol. Sci.-Chem., A18, 455 (1982).

9. E. Kirn, and J. K. Gillham, J. Appl. Polym. Sci., 20, 2045 (1976); I. Mita, "Kobunshi no Netsubunkai Kiko," in H. Kambe, Ed., "Kobunshi no Netsubunkai to Tainetsusei" (in Japanese), Baifukan 
Co., Tokyo, 1974, p 239.

10. T. Ogawa, T. Sawaguchi, T. Kuroki, and T. Ikemura, J. Jpn. Petrol. Inst., 24, 128 (1981).

11. H. Nanbu, M. Nakazima, and T. Ikemura, Preprints,
The 51th National Meeting of the Chemical Society of Japan, (II), 1985, p 932.

12. K. Tanabe and S. Takeshita, "Acid and Base Catalyst," Sangyotosho, Tokyo, 1967, p 180. 